\title{
The Obstacles Facing the Vocational Education (VE) Teachers in Public Primary Schools in Jordan
}

\author{
Dr. Sameer Aowad Kassab Shdaifat. \\ Al- Balqa' Applied University (BAU), Al - Huson, Head of the vocational education department Assistant \\ professor
}

\begin{abstract}
The present study aimed to explore the reality of the obstacles facing the vocational education (VE) teachers in public primary schools in Jordan from the perspective of those teachers. The researcher selected a sample consisting from 100 vocational education teachers. Those teachers were selected from the public primary schools in Jordan. The researcher developed a two part questionnaire. The first part collects demographic data from the respondents (i.e. gender and years of experience). The second part sheds a light on the obstacles facing the vocational education teachers. The examined obstacles include the obstacles related to (infrastructure, tools \& equipment, and the apparatus of occupational safety and health). It was found that the severity of the obstacles facing the vocational education teachers in public primary schools in Jordan is low from the perspective of those teachers. It was found that there isn't any statistically significant difference between the respondents' attitudes in this regard which can be attributed to (gender or years of experience). Several recommendations are proposed. For instance, the researcher recommends exerting effort by the Jordanian Ministry of Education to increase the level of occupational security and safety inside the workshops that are designated for the vocational education course. That can be done through providing these workshops with the necessary equipment that can raise the level of occupational security and safety.
\end{abstract}

Keywords: obstacles, vocational education

DOI: $10.7176 / \mathrm{JEP} / 11-8-11$

Publication date:March $31^{\text {st }} 2020$

\section{Introduction}

Many teachers today face many obstacles in the teaching-learning process. These obstacles have a negative impact on the teaching-learning process. For instance, they hinder teachers from meeting the intended goals. They include obstacles related teachers, courses, curricula, classroom environment, school environment and students. Countries provide much attention to vocational education and its courses. That is because vocational education plays a significant role in developing people. Vocational education (VE) aims at making one's personality well-developed in all the areas. It aims at developing one's life skills. Such skills are related to people's daily lives. Vocational education aims at developing one in three areas; cognitive, skills, and affective areas. Regarding the cognitive area, VE aims at enriching one's theoretical knowledge about various vocations and providing one with the necessary information. Regarding the skills area, VE aims at developing one's practical and vocational skills. Regarding the affective area, VE aims at developing one's attitudes towards vocations in general (Mahasneh \& Al-Azmi, 2015).

Khames \& Hammud (2018) suggest that vocational education aims at enabling one to practice a vocation in the future. Vocational education aims at enabling one to adjust himself with his/her society. It has become a very important education during the contemporary age. For instance, vocational education plays a significant role in developing one and enabling him/her to meet the requirements of his/her development

Recruiting competent and skilled vocational education teachers is highly needed. Having such teachers shall positively affect the quality of the provided education. In 1997, UNESCO adopted the International Standard Classification of Education (ISCED). Based on the latter classification, teaching the students enrolled in a vocational and technical education program requires having specific knowledge, and skills. It also requires meeting certain requirements (Ismail et al, 2018).

The term "vocation" refers to many occupations that requires special skills. Vocational institutions aim at developing one's skills and knowledge about a specific vocation in order to become capable of working. That shall enable one to meet the society's needs. Students enroll in vocational education programs, because they have a special interest in a particular vocation (Uwaifo \& Uwaifo, 2009).

The Jordanian Ministry of Education suggests that students may enrolled in vocational schools after finishing $10^{\text {th }}$ grade (i.e. during the secondary school stage (i.e. $11^{\text {th }}$ grade and $12^{\text {th }}$ grade). There are 210 vocational secondary schools for boys and girls in Jordan. The latter ministry suggests that students may receive vocational education in the following areas: the industrial, agricultural, hotel and tourism and home economics areas.

There are about 1,600 vocational education teachers working in the vocational schools in Jordan. Students enroll in vocational schools for a period of two years. Most of the VE male students in Jordan are majoring in industrial, hotel and agricultural areas. Most of the VE female students in Jordan are majoring in the home economics area 
There are major obstacles facing the VE teachers. Such obstacles include: the low status of vocational education teachers in society (Grollmann, 2008). The cost of managing VE institutions has been increasing. That is because the raw materials used in the teaching-learning process are expensive. It's because the world has been experiencing rapid developments in the field of technology. It should be noted that there are curricula-related obstacles facing the vocational education teachers. In the light of having many obstacles, many governments started to provide support for VE institutions (Jailani et al, 2016). Ismail et al. (2018) suggest that VE teachers play a significant role in providing the labor market with skillful graduates who have well-developed personalities. The challenges facing VE teachers in Jordan include the following challenges: (The Strategic Plan 2018 - 2022 of the Ministry of Education)

- Low financial incentives are provided to VE teachers

- There are difficulties in finding suitable buildings for VE schools. In addition, the costs of furnishing these buildings and providing them with the required equipment is high.

- Students are unwilling to join vocational schools.

- There are inadequate partnerships between vocational schools and the private sector

Hence, the present study aimed to shed a light on the obstacles facing the vocational education teachers in public primary schools in Jordan from the perspective of those teachers. It's necessary to shed a light on such obstacles. That is because VE plays a significant role in developing students and providing the labor market with qualified labor force.

\section{Statement of the problem}

The vocational education course provides students with theoretical and practical knowledge. Due to the significance of vocational education, VE teachers must be provided with a suitable environment. Those teachers must be also provided with an excellent infrastructure. Such infrastructure may include: workshops, and etc.. The researcher of the present study reviewed the relevant literature. Through making such a review, it was found that it's necessary to shed a light on the obstacles facing the vocational education teachers in public primary schools in Jordan. Thus, the problem of the present study is represented in the following question:

(What are the obstacles facing the vocational education teachers in public primary schools in Jordan from the perspective of those teachers?)

\section{The Study's Objectives and Questions:}

The present study aimed to explore the obstacles facing the vocational education teachers in public primary schools in Jordan from the perspective of those teachers. It aimed to answer these questions:

Q.1. What are the obstacles facing the vocational education teachers in public primary schools in Jordan from the perspective of those teachers?

Q.2. Is there any statistically significant difference between the respondents' attitudes which can be attributed to their (gender or experience)?

\section{The Study's Significance:}

The present study is significant due to the following reasons:

- The present study is significant because it aimed to explore the obstacles facing the vocational education teachers in public primary schools in Jordan from the perspective of those teachers. There is a need to conduct this study, because most researchers are concerned in the obstacles facing the teachers of other scientific and language courses. Thus, this study is significant because researchers do not provide adequate attention to the vocational education teachers and the obstacles facing them. Thus, this study participates in filling a gap in the relevant literature.

- The present study is significant because it provides decision makers with knowledge about the obstacles facing VE teachers in public primary schools in Jordan.

- The present study is significant because it provides recommendations and suggestions for addressing the obstacles facing VE teachers in public primary schools in Jordan.

\section{Definition of Terms:}

*Vocational education (VE): It refers to the education that aims at providing one with life skills in various areas. Such areas include the following: (households, tourism \& hotels, engineering, maintenance, agriculture \& environment, technology, and occupational safety and health (Mahasneh \& Al-Azmi, 2015, 6).

*Vocational education (VE) teachers: It refers to the teacher who has been developed in scientific and professional areas in order to teach students the vocational education course. VE teachers teach students the way they ought to think and learn. They serve as facilitators of knowledge. They are responsible for guiding students and leading them when carrying out educational activities (Khames \& Hammud, 2018, 142).

*Obstacles: (operational definition): They refer to the challenges facing the VE teachers in public primary schools 
in Jordan.

* The examined obstacles include obstacles related to (infrastructure, tools \& equipment, and apparatus of occupational safety and health).

\section{The Study's Limits:}

The study's limits are presented below:

* Spatial limits: The present study was conducted in the public primary schools in Jordan

*Temporal limits: The present study was conducting during January and February/ 2020

*Human limits: The present study targets the vocational education teachers in the public primary schools in Jordan

\section{Previous Studies:}

The researcher reviewed several studies. These studies are presented below:

Ismail et al (2018) aimed to explore the challenges that face VE teachers in public training institutions in Malaysia. A qualitative approach was adopted. Semi-structured interviews were conducted with 13 participants. The sample consists from 6 administrators and 7 VE teachers. Ismail et al (2018) found that there are various challenges facing VE teachers. Such challenges include the following challenges:

1)- Lack of motivation to develop students' skills

2)-Having poor skills in some areas and inadequate experience.

3)- Incapacity to meet the learning needs of the students with low grades. Meeting such needs require having teachers who are have high emotional intelligence level and willing to exert much effort

4)-Providing VE teachers with inadequate professional training courses due to having low budget.

5)- VE teachers experience much difficulty in writing articles

6)- VE teachers experience much difficulty in using English language when teaching students

7)-The workload of VE teachers is high

Khames \& Hammud (2018) aimed to explore the reality of the prevocational education course in primary schools. They aimed to explore that from the perspective of teachers and secretaries in the public schools in Latakia. The study's sample consists from 15 prevocational education teachers and 15 secretaries. Two questionnaires were developed; one of them is for teachers and the other one is for secretaries. The teacher's questionnaire includes 50 items. It sheds a light on 6 areas. The questionnaire of the secretaries consists from 129 items. It sheds a light on 7 areas. It was found that the effectiveness of the prevocational education is moderate from the teachers' perspective. It was found that the effectiveness of the prevocational education is low from the perspective of secretaries. It was found that there isn't any statistically significant difference between the teachers' attitudes which can be attributed to gender.

Boakye and Ampiah (2017) aimed to explore the challenges facing the newly qualified science teachers. Data were collected through using the observation method and conducting interviews. The content analysis method was also used for collecting information. It was found that such challenges include the following challenges:

1. Lack of the resources needed for the teaching-learning process.

2. Time management-related challenges

3. Students' inability to understand the lessons taught

4. Student indiscipline- related challenges

5. Lack of students' interest in science

6. Teachers' inability to complete the integrated science syllabus.

Jailani et al (2016) aimed to explore the challenges faced by VE teachers in three areas; governance, finance and training. In governance, stakeholders play a very significant role in sustaining the quality of vocational education. It was found that making partnerships between VE institutions and international and local institutions plays a significant role in developing VE teachers professionally. It was found that VE teachers face many financial challenges. It was found that there aren't adequate job opportunities provided to VE teachers.

Okoye \& Arimonu (2016) aimed to explore the challenges facing technical \& vocational education and training (TVET) institutions in Nigeria. It was found that the wages of the ones working in technical and vocational institutions must be fair and equitable. It was found that policies must be adjusted to address such challenges.

Mahasneh \& Al-Azmi (2015) aimed to explore the problems that face student-teachers in vocational education institutions while receiving the practical training. The study's sample consists from (30) student-teachers enrolled in AL-Shobak University College in Jordan. They were selected from two programs; (BA program and diploma program). A fifty four item questionnaire was used. It was found that the severity level of the challenges facing the student-teachers in vocational education institutions is moderate. Such challenges include: challenges related to curriculum and supervision. It was found that there are statistically significant differences between the respondents' attitudes which can be attributed to the academic program.

Kadbey et al. (2014) aimed to explore the challenges facing the science teachers who work in the public schools located in Abu Dhabi. They used a survey for collecting data from 248 teachers who work in public 
primary schools. It was found that there are several challenges facing the teachers who work in public schools. Such challenges may include: students' behavioral problems and lack of resources. They include challenges related to curricula and parental support. In addition, it was found that teachers aren't provided with adequate professional support. Such support is attributed to the poor educational policies.

Gloria \& Efajemue (2011) aimed to explore the problems facing the ones receiving vocational teacher education in Rivers state. The population of the study consists from all the ones receiving vocational teacher education in Rivers state. The study's sample consists from 288 individuals who were receiving vocational teacher education in Rivers State. A structured questionnaire was used to collect data. Frequencies, and percentages were calculated. The Chi-Square (X2) test was conducted to analyze data. It was found that there are several problems facing the ones receiving vocational teacher education in Rivers State. Such problems include: poor planning, and poor infrastructure.

Uwaifo \& Uwaifo (2009) aimed to explore the problems facing the vocational education teachers in Nigeria. It was found that it's necessary to provide vocational and technical education teachers with effective and adequate training courses in Nigeria. It was found that more attention must be provided to the development of those teachers in Nigeria.

\section{The Study's Methodology:}

A descriptive analytical approach was adopted. That's because this approach is the most suitable one for this study. The latter approach is adopted by many researchers for offering readers a sensory description for things and items. It can be adopted to determine whether certain sensory attributes are deemed accepted or not. It may be adopted by researchers to explore variables and their dimensions and constituents (Lawless and Heymann, 1999).

\section{Population}

The study's population consists from all the vocational education teachers who work in public primary schools in Jordan.

\section{Sample}

The sample was selected through using the stratified random sampling method. It consists from 100 female and males vocational education teachers. Those teachers were selected from public primary schools that are affiliated with Al-Zarqa' Aloola Directorate of Education. They were also selected from public primary schools that are affiliated with Al-Zaraqa' Althaneye Directorate of Education. Data about the sample is listed in table 1 below Table (1): Demographic data about the sample

\begin{tabular}{|l|l|l|}
\hline Variable & Category & Frequency \\
\hline \multirow{5}{*}{ Gender } & Male & 42 \\
\cline { 2 - 3 } & Female & 58 \\
\cline { 2 - 3 } & Total & 100 \\
\hline \multirow{5}{*}{ Experience } & Less than 5 years & 39 \\
\cline { 2 - 3 } & $5-15$ years & 41 \\
\cline { 2 - 3 } & More than 15 years & 20 \\
\cline { 2 - 3 } & Total & 100 \\
\hline
\end{tabular}

$\mathbf{N}=\mathbf{1 0 0}$

\section{Instrument:}

This study aimed to explore the obstacles facing the obstacles facing the vocational education (VE) teachers in public primary schools in Jordan from their perspective. Thus, a two part questionnaire was used for collecting data. The first part aims at collecting demographic data (i.e. gender and years of experience). The second part aims at collecting data about the obstacles related to (infrastructure, tools \& equipment, and apparatus of occupational safety and health). The five point Likert scale was adopted. This scale consists from the following categories:

- To a very great extent

- To a great extent

- To a moderate extent

- To a very little extent

- To a little extent

The scores of the five point Likert scale are: 5, 4, 3, 2 and 1 respectively.

\section{Validity of the instrument}

The researcher measured the validity of the instrument through passing the questionnaire to a panel of experts to provide their opinion. Those experts suggested that the questionnaire is highly capable of meeting the study's goals. 
They suggested that there isn't any need for making adjustments to the questionnaire.

\section{Reliability of the instrument}

To measure the reliability of the instrument, the Cronbach alpha coefficient values were calculated. The total Cronbach alpha coefficient value is 0.901 . Thus, the questionnaire is highly reliable.

\section{Data collection methods:}

The researcher used two types of data:

Primary data: It refers to the data that was collected through using the five point Likert questionnaire Secondary data: It refers to the data that was obtained through reviewing the relevant books, studies and journals. Statistical analysis methods

To meet the goals of the present study, the researcher used the SPSS program to analyze the collected data. In addition, the following statistical analysis methods were used for analyzing data:

- The researcher calculated frequencies to identify the demographic description of the respondents

- The researcher calculated means and standard deviations in order to identify the attitudes of the respondents

- The researcher calculated Cronbach alpha coefficient values to measure the reliability of the instrument

- The researcher conducted the multiple regression analysis

\section{Statistical criteria for classifying means:}

The researcher adopted the following statistical criteria for classifying means:

1-2.33: low

2.34-3.67: moderate:

3.68-5: high

\section{The study's results:}

\section{Results related to the first question:}

Q.1. What are the obstacles facing the vocational education teachers in public primary schools in Jordan from the perspective of those teachers?

To answer this question, means and standard deviations are calculated. These values are presented through table (2) below:

Table (2): Means and standard deviations to identify the obstacles facing the vocational education teachers in public primary schools in Jordan from the perspective of those teachers

\begin{tabular}{|l|l|l|l|l|l|}
\hline No. & Type of obstacle & Std. & Mean & Rank & Level \\
\hline 3 & Infrastructure & 0.901 & 2.51 & 1 & Moderate \\
\hline 2 & Tools \& equipment & 0.911 & 2.29 & 2 & Low \\
\hline 1 & Apparatus of occupational safety and health & 0.915 & 2.21 & 3 & Low \\
\hline & Total & 0.90 & 2.32 & & Low \\
\hline
\end{tabular}

Based on table (2), it was found that the severity of the obstacles facing VE teachers in public primary schools in Jordan is low from their perspective. That is because the mean is 2.32 which is low. It was found that the severity of the infrastructure-related obstacles is moderate. That is because the relevant mean is 2.51 . The latter mean is ranked first. It was found that the severity of the obstacles related to tools \& equipment is low. That is because the relevant mean is 2.29 . The latter mean is ranked second. It was found that the severity of the obstacles related to the apparatus of occupational safety and health is low. That is because the relevant mean is 2.21 . The latter mean is ranked third. The latter result may be attributed to the fact that there VE teachers are provided with a good infrastructure. For instance, all public primary schools in Jordan are provided with VE workshops.

\section{Results related to the second question}

Q.2. Is there any statistically significant difference between the respondents' attitudes which can be attributed to their (gender or experience)?

\section{First: Results related to gender:}

To explore whether there is any statistically significant difference between the respondents' attitudes which can be attributed to their (gender), means and standard deviations are calculated. These values are calculated to identify the respondents' attitudes in accordance with the respondents' gender. They are presented in table (3) below: 
Table (3): Means and standard deviations for identifying the respondents' attitudes in accordance with the respondents' gender

\begin{tabular}{|l|l|l|l|l|l|}
\hline Gender & Std. & \multicolumn{1}{|c|}{ Mean } & df. & Calculated F value & Sig. \\
\cline { 1 - 3 } Male & 0.60 & 2.22 & 2 & 0.302 & \multirow{2}{*}{0.155} \\
\hline Female & 0.59 & 2.16 & & & \\
\hline
\end{tabular}

Based on table (3), it was found that there isn't any statistically significant difference -at the statistical significance level of $\mathrm{a}=0.05$ - between the respondents' attitudes which can be attributed to their (gender). That indicates that VE female teachers share similar views with VE male teachers. The latter result is consistent with the result concluded by Khames \& Hammud (2018). The latter researchers found that there isn't any significant difference between respondents' views which can be attributed to gender.

\section{Second: Results related to experience:}

To explore whether there is any statistically significant difference between the respondents' attitudes which can be attributed to their (experience), means and standard deviations are calculated. These values are calculated to identify the respondents' attitudes in accordance with the respondents' experience. They are presented in table (4) below:

Table (4): Means and standard deviations for identifying the respondents' attitudes in accordance with the respondents' experience

\begin{tabular}{|l|l|l|l|l|}
\hline Variable & Descriptive statistics & $\begin{array}{l}\text { Apparatus of occupational } \\
\text { safety and health }\end{array}$ & $\begin{array}{l}\text { Tools } \\
\text { equipment }\end{array}$ & Infrastructure \\
\hline \multirow{2}{*}{$\begin{array}{l}\text { Less than } \\
\text { years }\end{array}$} & Mean & 2.39 & 2.31 & 2.36 \\
\cline { 2 - 5 } $5-15$ years & Standard deviation & 0.73 & 0.62 & 0.57 \\
\cline { 2 - 5 } & Mean & 2.21 & 2.39 & 2.11 \\
\hline \multirow{2}{*}{$\begin{array}{l}\text { More than } \\
\text { years }\end{array}$} & Standard deviation & 0.60 & 0.70 & 0.69 \\
\hline \multirow{2}{*}{ Total } & Mean & 2.38 & 2.24 & 2.22 \\
\cline { 2 - 5 } & Standard deviation & 0.89 & 0.68 & 0.68 \\
\cline { 2 - 5 } & Mean & 2.35 & 2.29 & 2.36 \\
\hline
\end{tabular}

Based on table (4), it appears that there are differences between respondents' attitudes which can be attributed to the years of experience. In order to identify whether these differences are statistically significant or not, one way analysis of variance (ANOVA) was conducted. The results of the latter analysis is presented in table (5).

Table (5): The results of the one way analysis of variance (ANOVA)

\begin{tabular}{|l|l|l|l|l|l|l|}
\hline Variable & Area & $\begin{array}{l}\text { Sum of } \\
\text { square }\end{array}$ & $\begin{array}{l}\text { Mean } \\
\text { square }\end{array}$ & $\begin{array}{l}\text { Calculated falue } \\
\text { value }\end{array}$ & Sig. \\
\hline $\begin{array}{l}\text { Years } \\
\text { experience }\end{array}$ & $\begin{array}{l}\text { Apparatus of occupational } \\
\text { safety and health }\end{array}$ & 0.459 & 2 & 0.230 & 0.656 & 0.521 \\
\hline & Tools \& equipment & 0.766 & 2 & 0.383 & 0.751 & 0.474 \\
\hline & Infrastructure & 0.456 & 2 & 0.228 & 0.637 & 0.531 \\
\hline
\end{tabular}

Based on table (5), it was found that there isn't any statistically significant difference -at the statistical significance level of $\mathrm{a}=0.05$ - between the respondents' attitudes which can be attributed to (experience). That indicates that the sampled VE teachers of various years of experience share similar views about the obstacles facing them.

\section{Conclusion and Recommendations:}

It was found that the severity of the obstacles facing the vocational education teachers in public primary schools in Jordan is low from the perspective of those teachers. It was found that there isn't any statistically significant difference between the respondents' attitudes in this regard which can be attributed to (gender or years of experience). The latter results indicate that the Jordanian Ministry of Education has been providing much attention to vocational education teachers and public primary schools. They indicate that the educational policies adopted by the Jordanian Ministry of Education are effective.

In the light of the aforementioned results, the researcher recommends the following:

Exerting more effort by the Jordanian Ministry of Education to increase the level of occupational security and safety inside the workshops that are designated for the vocational education course. That can be done through providing these workshops with the necessary equipment that can raise the level of occupational security and safety.

- Providing more attention to the infrastructure of public schools. That can be done through providing VE workshops at public schools with all the needed equipment and supplies. Such equipment and supplies shall enable vocational education teachers to carry out all the activities mentioned in the curricula. 


\section{References}

Ismail, K., MohdNopiah, Z. \&MohdSattar, R. (2018) Challenges Faced By Vocational Teachers In Public Skills Training Institutions: A Reality In Malaysia. Journal Of Technical Education And Training (Jtet) Vol. 10, No.2p12-27.

Grollmann, Philipp (2008) The Quality of Vocational Teachers: teacher education, institutional roles and professional reality. European Educational Research Journal Volume 7 Number 4 p535-547.

Jailani .Yunos ., Lai CheeSern ., Tee TzeKiong ., Hamdan, Nor. (2016) The Issues And Challenges Of Vocational Teacher Education Program. Proceedings Of The 1 St Annual International Seminar On Transformative Education And Educational Leadership (Aisteel) E-Issn: 2548-4613.

Fix G. M., Ritzen , H., Pieters M., and Kuipe, W. (2019) Effective curricula for at-risk students in vocational education: a study of teachers' practice. Fix et al. Empirical Res Voc Ed Train (2019) 11:1 https://doi.org/10.1186/s40461-018-0076-5

Gloria, L., \&Efajemue, O. (2011) PROBLEMS OF VOCATIONAL TEACHER EDUCATION IN RIVERS STATE, NIGERIA. Proceedings Of The 2011 International Conference On Teaching, Learning And Change (C) International Association For Teaching And Learning (IATEL).

Okoye, R., \&Arimonu, M. (2016) Technical and Vocational Education in Nigeria: Issues, Challenges and a Way Forward.Journal of Education and PracticeVol.7, No.3, p 113-128.

Uwaifo, V., \&Uwaifo, U. (2009) Training technology and vocational education teachers for the new 9-3-4 education system in Nigeria: Its problems and prospects. International NGO Journal Vol. 4 (4), pp. 160-166.

The Jordanian Ministry of Education, Strategic Plan 2018 - 2022.

Khames, F., \& Hammud, H., (2018) The Reality of Teaching Prevocational Education Course in Primary Education from the Viewpoint of Teachers and Secretaries. Journal of Educational Science Studies, Volume (42) No. (2).

Mahasneh, Omar, and Al-Azmi, Alya (2015) The Effect of Using the Workshop Conversation Approach with the Five-Student Groups in Achievement of Tenth Grade Students in PreVocational Education. Journal of Educational Science Studies Vol 42. N 1.

Kadbey, H.; Dickson, M.; and McMinn, M. (2014). Primary Teachers' Perceived Challenges in Teaching Science in Abu Dhabi Public Schools. 5th World Conference on Learning, Teaching and Educational Leadership, WCLTA.

Lawless H., and Heymann H. (1999) Descriptive Analysis. In: Sensory Evaluation of Food. Food science text series. Springer, Boston, MA

Boakye, C. and Ampiah, J. (2017). Challenges and Solutions: The Experiences of Newly Qualified Science Teachers. SAGE Open. 7(2).

Acknowledgment:

The researcher would like to thank the respondents for participating in the present study. 